\title{
Micropropagation and Somatic Embryogenesis Induction of Gardenia jasminoides Plants
}

\author{
Mohamed K. Gaber ${ }^{1}$ and Ahmed A. Barakat ${ }^{2}$
}

\begin{abstract}
Gardenia jasminoides Ellis is an evergreen plant with fragrant creamy white flowers and glossy, darkgreen leaves, belongs to family Rubiaceae and member of the genus Gardenia. The current study aimed to afford a new technique for in vitro propagation and callus induction of G. jasminoides by using single nodes excised from soft cuttings using full strength MS salts supplemented with $30 \mathrm{~g} / \mathrm{l}$ sucrose, $4 \mathrm{~g} / \mathrm{l}$ gelrite and different concentrations of plant growth regulators. Generally, the current study showed that NAA and BA at 0.0 and $1.0 \mathrm{mg} / \mathrm{l}$, respectively gave rise to the best results for initiation stage. Meanwhile, fortified the basal MS medium with BA and NAA at 2.0 and $0.250 \mathrm{mg} / \mathrm{l}$, consecutively; resulted in the best results with respect to multiplication stage. Regarding rhizogenesis, the neoformed shoots produced from vegetative multiplication stage were rooted successfully upon cultured on MS medium supplemented with $1.0 \mathrm{mg} / \mathrm{l}$ IBA and NAA at either 0.250 or $0.500 \mathrm{mg} / \mathrm{l}$, whereas the highest number of roots was recorded besides callus induction. Regarding embryonic callus induction, adding 2,4-D at $1.0 \mathrm{mg} / \mathrm{l}$; enhanced embryonic callogenesis. Neoformed plantlets were acclimatized $e x$ vitro and in vivo vigorously in mixture of perlite and peatmoss at $(1: 1, \mathrm{v} / \mathrm{v})$, which resulted in the highest percentage value of survival / percent $(100 \%)$ and successfully flowered and showed true-to-type plants ex vitro.
\end{abstract}

Keywords: Gardenia jasminoides, Rubiaceae, tissue culture, plant growth regulators, embryonic callus.

\section{INTRODUCTION}

Gardenia jasminoides, formerly called gardenia (cape jasmine). It is a origan to southern of China and Japan and there shrubs are evergreen with glossy, thick, greenish leaves. It belongs to Rubicaceae family, particularly noted for its extremely fragrant white flowers and is often grown in double flowers (Graf, 1981). Flowers bloom all around the year in climates warm regions, but more typically opening through the late spring until early summer in cooler climates in the northern part of its growing range. Gardenia are grown as pot or larger container plants (Wilkins, 1986). Under greenhouse conditions these plants can growth easily, but can also thrive when placed outdoors during summer season and returned to moderate indoor temperatures in the fall. It is a popular plant used as a cut flower, screens, hedges, borders or ground covers. Micropropagation of ornamental, medicinal and aromatic plants has been used via single nodes, axil buds and shoot tips, and provide higher rates of proliferation per each starting explant (Razdan, 2003; George et al., 2008; Chavan et al., 2014). In conventional propagation, terminal cutting of $G$. jasminoides results in a reduced multiplication rate. Hence, its micropropagation via in vitro organogenesis using modified Murashige and Skoog (1962) medium (MS) offers higher proliferation rate per each starting explant (Economou and Spanoudaki, 1985). The most important divisions of the plant growth regulators are provided into tissue culture medium, are both cytokinins and auxins and. The relative efficacy of auxins, mainly and their relation to cytokinin ratio on morphogenesis of cultured tissues are well established by Skoog and Miller (1957) and still remain as the source for plant tissue culture manipulations. The medium must be fortified with plant growth agents for enhancement of both growth and development of cultured explants. Plant growth agents exert dramatic effects at reduced levels. They regulate and organize both initiation and development of organized organs (shoots, roots and embryos) on the cultured explants either on semisolid or in liquid medium cultures. They stimulate both cell division and expansion (Duhoky and Rasheed, 2010). In gardenia, Al-Juboory et al., (1998) reported that the cytokinin mode of action exhibited the best shoot proliferation was obtained from gardenia leaves treated with TDZ, ZEA and BA as compared to $2 \mathrm{iP}$ and KIN whereas the produced shoots were the longer in culture media that augmented with either $2 \mathrm{iP}$ or BA. The best medium for micropropagation of Gardenia jasminoides was MS medium fortified with BA and IBA at $1 \mathrm{mg} / \mathrm{l}$ and $0.1 \mathrm{mg} / \mathrm{l}$, respectively, with a multiplication rate of 5.33 neoformed shoots, with shoot length and leaf number as an average $4.73 \mathrm{~cm}$ and 4.36 , consecutively (Jarrar and Bayerly, 2011). Lakshmia and Reddy (2012) found that maximum shoot number of G. resinifera was recorded on MS medium (1962) supplied with BA 
$(4.0 \mathrm{mg} / \mathrm{l})$ and IAA $(0.5 \mathrm{mg} / \mathrm{l})$, and about $70 \%$ of root induction was taken place on half-strength MS medium fortified with IBA $(4.0 \mathrm{mg} / \mathrm{l})$. Farzinebrahimi et al., (2014) observed that the biggest callogenesis and the maximum fresh and dry weights of $G$. jasminoides callus were induced on MS medium plus NAA and 2,4-D at 3.0 and $2.0 \mathrm{mg} / \mathrm{l}$, each in turn. Salim and Hamza (2017) showed that the maximum mean values of shoots length, shoot number, number of nodes and leaflets number per shoot of $G$. jasminoides were obtained when MS medium was augmented with combination $3.0 \mathrm{mg} / \mathrm{l} \mathrm{TDZ}$ $+0.3 \mathrm{mg} / \mathrm{l} \mathrm{IAA}$; whereas the concentration $1.0 \mathrm{mg} / \mathrm{l}$ IBA; gave highest average of roots number. Callogenesis of gardenia can be induced easily from various parts of the plants (Mizukami et al., 1983; Dumanois et al., 1984) and best callus growth was derived from leaf explants cultured on MS medium. Various auxins such as 2,4-D, NAA, and IAA were tested for induction and subculture of the callus in the presence or absence of cytokinins. Dumanois et al. (1984) manifested that white loose callus tissues were formed from leaf explants in the presence of 2,4-D (0.2 $\mathrm{mg} / \mathrm{l})$ and $2 \mathrm{iP}(0.2 \mathrm{mg} / \mathrm{l})$ or BAP $(1 \mathrm{mg} / \mathrm{l})$ while brownwhite callus tissues with newly formed roots were obtained in the presence of NAA $(1 \mathrm{mg} / \mathrm{l})$ and kin $(0.5$ $\mathrm{mg} / \mathrm{l})$.

The aim of the present work is to study the possibility of tissue culture technology for the clonal mass propagation of Gardenia jasminoides via both microprpagation and somatic embryogenesis.

\section{MATERIAL AND METHODS}

This study was conducted at the laboratory of plant tissue culture of Plant Production Department, The Faculty of Agriculture (Saba-Basha), Alexandria University during both study seasons of 2017 and 2018.

Plant Materials (Source of Explants and Explant Preparation):

Shoots of Gardenia jasminoides, about $15 \mathrm{~cm}$ in length were picked up from plants grown in the greenhouse of Antoniades Botanical Garden, Horticultural Res. Institute, Agric. Res. Center, Alexandria, Egypt. Soon after collection, the shoots were preserved in transparent plastic bags and transported directly to the laboratory. After leaves' removal, selected shoots were rinsed under running tap water for 60 minutes, followed by tap water and liquid soapy for 15 minutes, followed by five-minute rinses in sterile distilled water. Then they were cut into shorter sections $(c a .1 .5 \mathrm{~cm})$ long including the single nodes with axillary bud. The shoots were sterilized by soaking in the Mercuric Chloride solutions $(0.1 \%, \mathrm{w} / \mathrm{v})$ for 10 minutes. The disinfected explants were rinsed thoroughly 5 times with double autoclaved distilled water, and the ends of explants exposed to sterile solution were trimmed. The nutrient media contained half inorganic and organic constituents according to (Murashige and Skoog, 1962), then $30 \mathrm{~g} / \mathrm{l}$ of sucrose, $100 \mathrm{mg} / \mathrm{l}$ of myo-inositol, and different vitamins in addition to several studied growth regulators were added according to the purpose of the experiment and adding $4 \mathrm{~g} / \mathrm{l}$ gelrite $(\mathrm{w} / \mathrm{v})$. In vitro propagation technique for the current study was carried out as follows:

1. Initiation stage, whereas various levels of NAA and BA were examined to detect their impact on growth performance during initiation stage either alone or combined together. The auxin Naphthaleneacetic acid (NAA) was used at $0.0,0.250,0.5$ and $1.0 \mathrm{mg} / \mathrm{l}$ and the cytokinin Benzyladenine (BA) at 0.0, 0.125 and $0.250 \mathrm{mg} / \mathrm{l}$ lonely or in combination with NAA. Ten explants were planted per each treatment. Cultures were incubated in the growth room at $25 \pm 1^{\circ} \mathrm{C}$ under light conditions of 16 light hours and light intensity of $c a .1000$ lux and $8 \mathrm{hr}$. of incubation darkness. After 5 weeks of culture, the well-defined data were collected.

2. Multiplication stage, whereas the neoformed propagules of the initiation stage was sectioned into single node explants, which were cultured, randomly, on the multiplication media which supplemented with BA at concentrations of 0.0, 1.0, 2.0 and 4.0 $\mathrm{mg} / \mathrm{l}$ and NAA at $0.0,0.250,0.5 \mathrm{mg} / \mathrm{l}$ alone or in combinations together.

3. Rooting stage, the shoots of about $3 \mathrm{~cm}$ in length were cultured into MS medium including various levels of IBA and NAA (one shoot for each jar and each treatment were represented by ten jars). The effect of IBA and NAA added to the culture medium for shoots rhizogenesis was studied by carrying out several separate experiments by adding IBA with $(0.0,0.250,0.5$ and $1.0 \mathrm{mg} / \mathrm{l})$ and NAA with $(0.0$, 0.250 and $0.5 \mathrm{mg} / \mathrm{l})$, all these treatments were examined on full strength salt MS medium.

Generally, each treatment was represented by 10 jars, one explant per jar containing $20 \mathrm{ml}$ medium. The culture jars and the tested media were solidified and autoclaved as mentioned earlier. The explants were cultured on the sterilized media, vertically, and incubated in growth room as reported earlier. After 5 weeks of culture, the data were collected.

4. Somatic embryogenesis, from in vitro propagules, node cuttings of propagules were used as explants, which were cultured on MS medium augmented with various levels of 2,4-D at nil (0.0), 0.5, 1.0, 2.0 and $4.0 \mathrm{mg} / \mathrm{l}$. cultures were incubated in the room under growth conditions that reported earlier in darkness for 10 days, then exposed to rooting condition. 
5. Acclimatization of neoformed plantlets, the neoformed plantlets produced from rooting stage were washed out of solidified medium under running tap water, followed by immersing them into RizolexT50 WP (1g/l) fungicide for $25 \mathrm{sec}$. They were, then, transplanted ex vitro in small plastic pots $(10 \mathrm{~cm}$ diameter), plastic pots contained an autoclaved mixture of the perlite $(0.0,1.0,2.0$ and 3.0 volume) and peatmoss (0.0, 1.0 and 2.0 volume); and one constant volume of washed and autoclaved sand. Then, they were arranged in a factorial experiment and finally placed in transparent plastic bags (ex vitro), to maintain high relative humidity at $80 \%$ (RH) and $28 \pm 1^{\circ} \mathrm{C}$, for hardening-off. However, the tested pots with different media were rearranged randomly weekly within the same plot to devoid the experimental error. Ten days later, the plastic bags were perforated for gaseous exchange, then transferred into plastic house (in vivo) and continued for further hardening. After four weeks, the plastic bags were removed and the acclimatized plantlets were watered, as needed and fertilized, weekly, with $\mathrm{N}: \mathrm{P}_{2} \mathrm{O}_{5}: \mathrm{K}_{2} \mathrm{O}$ (20:20:20) equivalent to $1 \mathrm{~g} / \mathrm{l}$.

\section{Experimental design and statistical analysis}

All the experiments carried out during this study were designed as factorial experiments layout in completely randomized design (Gomez and Gomez, 1984). All collected data were subjected to statistical analysis using ANOVA method and separation between means were compared by Duncan's multiple range test (Steel et al., 1997) and significance was determined at $\mathrm{p} \leq 0.05$. Generally, the following characters were recorded per propagule at initiation, multiplication, rooting, somatic embryogenesis and acclimatization stages after 5 weeks from culture:

1. Mean number of shoots formed/propagule.

2. Mean shoot length $(\mathrm{cm}) /$ propagule.

3. Mean number of leaflets formed/propagule.

4. Mean number of nodes formed/propagule.

5. Mean number of roots formed/propagule.

6. Percentage of embryogenic callus.

7. Mean callus size / propagule, was determined, macroscopically, and for statistically convenience, the minus or plus symbols were converted to a numerical code as follows: (-), $0 ;(+), 1 ;(++), 2$; $(+++), 3 ;(++++), 4$. These symbols denote to absence of callus formation, low, moderate, high, and intensive embryonic callus formed per propagule, respectively.

8. Concerning the acclimatization stage, the following traits were determined:

a. Average survival percentage (\%)/plant.

b. Average number of neoformed shoots/plant.

c. Average plant height $(\mathrm{cm}) /$ plant. d. Average number of neoformed leaflets/plant.

\section{RESULTS AND DISCUSSION}

\section{Initiation stage:}

Results in Table (1) and Figure (1) describe the effect of various levels of both growth regulators (NAA and BA) and their combinations on the studied characters of $G$. jasminoides. Concerning the main effect of BA concentrations, there is a direct proportional relationship between the mean number of shoots formed per propagule and BA levels; whereas, the highest level of BA $(0.250 \mathrm{mg} / \mathrm{l})$; gave rise to the highest mean value of number of shoots per propagule the given trait (2.30). This finding may be attributed to cytokinin deficiency in stimulation cell division and morphogenesis (shoot initiation/bud formation) in tissue culture and break of apical dominance and release the growth of lateral buds (Stern et al., 2004; Duhoky and Rasheed, 2009). On the other side, NAA had not significant effect on the same trait. Meanwhile, the interaction between both growth regulators exerted significant $(p \leq 0.05)$ effect. However, the absence of NAA and presence of BA at $0.250 \mathrm{mg} / \mathrm{l}$; resulted in the highest mean value (3.00). Respecting the shoot length per propagule, both growth regulators and their interactions have exerted significant $(p \leq 0.05)$ effects on the specific trait. In terms of NAA as a main effect, augmenting the culture medium with NAA at $1.00 \mathrm{mg} / \mathrm{l}$; led to the highest mean value of shoot length per propagule (1.57). On the other side, with respect to the main effect of BA the results disclosed that augmenting MS-basal medium at $0.125 \mathrm{mg} / 1$; resulted in the highest mean values of the above- mentioned trait (1.41). This result is in agreement with that of Kyoichi et al. (1987). The first order interaction between both applied levels of NAA and BA at 1.0 and $0.0 \mathrm{mg} / \mathrm{l}$, each in turn; led to the longest mean value of the shoot length per propagule (1.72). As for the mean number of leaflets and the number of nodes formed per propagule, the effect of both NAA and BA, exerted non-significant $(p \geq 0.05)$ effect. On the other hand, the interaction between both growth regulators exerted a significant $(p \leq 0.05)$ effect on the leaflets and nodes numbers. The interaction between both BA and NAA at 0.250 and $0.125 \mathrm{mg} / \mathrm{l}$, respectively; brought about the highest mean values (11.80 and 10.20, respectively). These results are in agreement with those found by Economou and Spanoudaki (1986) and Pasqual and Audo (1989) who reported the necessity of using of cytokinins and auxins either singly or in combination for inducing cell divisions, as well as for the proliferation of shoots of many plants. 
Table 1. Effect of different levels of NAA and BA (mg/l) and their combinations on the initiation stage of Gardenia jasminoides cultured in vitro for 5 weeks

\begin{tabular}{|c|c|c|c|c|c|c|c|c|c|}
\hline \multirow[b]{2}{*}{ Characters } & \multirow{2}{*}{$\begin{array}{c}\text { BA } \\
\text { levels } \\
(\mathrm{mg} / \mathrm{l})\end{array}$} & \multicolumn{4}{|c|}{ NAA levels (mg/l) } & \multirow{2}{*}{$\begin{array}{c}\text { Mean } \\
\text { BA }\end{array}$} & \multicolumn{2}{|c|}{ Significance } & \multirow[b]{2}{*}{ NAAXBA } \\
\hline & & 0.000 & 0.250 & 0.500 & 1.000 & & NAA & BA & \\
\hline \multicolumn{10}{|c|}{ (a) Mean number of shoots formed/propagule: } \\
\hline & 0.000 & 1.42 & 2.36 & 1.55 & 1.42 & 1.69 & $\mathrm{~ns}$ & $* *$ & $* *$ \\
\hline & 0.125 & 2.00 & 1.77 & 1.71 & 1.72 & 1.80 & & & \\
\hline & 0.250 & 3.00 & 1.40 & 2.00 & 2.80 & 2.30 & & & \\
\hline Mean(NAA) & & 2.14 & 1.84 & 1.75 & 1.98 & & & & \\
\hline L.S.D. (0.05) & & & & & & & 0.40 & 0.35 & 0.69 \\
\hline \multicolumn{10}{|c|}{ (b) Mean shoot length $(\mathrm{cm}) /$ propagule: } \\
\hline & 0.000 & 1.14 & 1.42 & 0.92 & 1.72 & 1.30 & $* *$ & $*$ & $* *$ \\
\hline & 0.125 & 1.40 & 1.64 & 1.15 & 1.43 & 1.41 & & & \\
\hline & 0.250 & 1.09 & 0.85 & 1.26 & 1.57 & 1.19 & & & \\
\hline Mean(NAA) & & 1.21 & 1.30 & 1.11 & 1.57 & & & & \\
\hline L.S.D. (0.05) & & & & & & & 0.23 & 0.20 & 0.40 \\
\hline \multicolumn{10}{|c|}{ (c) Mean number of leaflets formed/propagule: } \\
\hline & 0.000 & 8.40 & 9.20 & 9.40 & 6.00 & 8.25 & $\mathrm{~ns}$ & ns & $* *$ \\
\hline & 0.125 & 10.20 & 11.80 & 5.80 & 9.00 & 9.20 & & & \\
\hline & 0.250 & 9.70 & 6.00 & 9.40 & 10.00 & 8.78 & & & \\
\hline Mean(NAA) & & 9.43 & 9.00 & 8.20 & 8.33 & & & & \\
\hline L.S.D. (0.05) & & & & & & & 1.26 & 1.09 & 2.17 \\
\hline \multicolumn{10}{|c|}{ (d) Mean number of nodes formed/propagule: } \\
\hline & 0.000 & 4.40 & 4.70 & 4.70 & 3.00 & 4.20 & $\mathrm{~ns}$ & ns & $* *$ \\
\hline & 0.125 & 5.10 & 6.10 & 2.90 & 4.50 & 4.65 & & & \\
\hline & 0.250 & 4.90 & 3.00 & 4.70 & 5.00 & 4.40 & & & \\
\hline Mean(NAA) & & 4.80 & 4.60 & 4.10 & 4.17 & & & & \\
\hline L.S.D. (0.05) & & & & & & & 0.64 & 0.55 & 1.10 \\
\hline \multicolumn{10}{|c|}{ (e) Mean number of roots formed/propagule: } \\
\hline & 0.000 & 0.00 & 0.00 & 1.50 & 0.00 & 0.38 & $* *$ & ns & $*$ \\
\hline & 0.125 & 0.00 & 0.00 & 1.40 & 0.00 & 0.35 & & & \\
\hline & 0.250 & 0.00 & 0.00 & 1.20 & 0.00 & 0.30 & & & \\
\hline Mean(NAA) & & 0.00 & 0.00 & 1.37 & 0.00 & & & & \\
\hline L.S.D. (0.05) & & & & & & & 0.52 & 0.45 & 0.90 \\
\hline
\end{tabular}

L.S.D. $(0.05)=$ Least significant difference test at 0.05 level of probability.

*, **: Significant or highly significant. ,ns: not significant

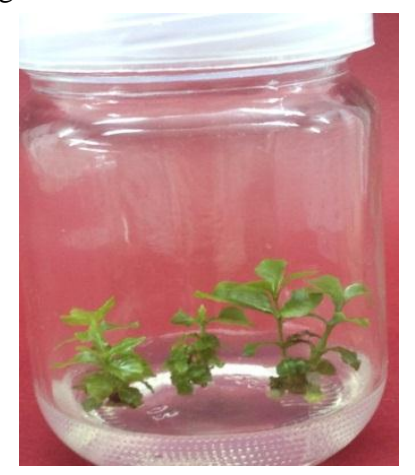

Fig. 1. Initiation stage of Gardenia jasminoides nodal explants cultured on MS medium supplemented with NAA at $1.0 \mathrm{mg} / \mathrm{l}$, after 5 weeks of culture 
With respect to the number of roots formed per propagule, NAA levels had a significant $(p \leq 0.05)$ effect on this trait. The highest mean value (1.37) was recorded due to applying $0.5 \mathrm{mg} / \mathrm{l} \mathrm{NAA}$ to the culture medium. On the other hand, BA had non-significant $(p \geq 0.05)$ effect on the mean number of roots per propagule. Meanwhile, the interaction between both growth regulators exerted significant $(p \leq 0.05)$ effect. However, the combination of NAA at $0.5 \mathrm{mg} / 1$ and absence of BA; resulted in the highest mean value (1.5) of the mean number of roots per propagule. These results are in parallel with those reported by Snir (1982); Penuela et al. (1987); Duhoky and Rasheed (2010) who ascertained the importance of the auxin NAA in rhizogenesis medium.

\section{Multiplication stage:}

The results presented in Table (2) and Figure (2) reveal the effect of both growth regulators and their combinations on the multiplication stage of $G$. jasminoides. As for the main effect of $\mathrm{BA}$, it was noticed that fortifying MS medium with BA at $2.0 \mathrm{mg} / \mathrm{l}$, brought about the highest mean value (3.17) of the mean number of shoots formed per propagule, followed by 4.0 $\mathrm{mg} / \mathrm{l} \mathrm{BA}$ (2.97), compare to the absence of BA or its presence at $1.0 \mathrm{mg} / \mathrm{l}$, which led to the lowest values of this character. On the other extreme, the main effect of NAA indicated that supplying MS-basal medium with NAA at either 0.250 or $0.500 \mathrm{mg} / \mathrm{l}$; recorded the highest mean value of the defined trait (2.63). This finding may be taken place due to BA as the most effective cytokinin in cell division and enlargement as compared with the other cytokinins (Gruselle et al., 1987). Meanwhile, the interaction between BA at $2.000 \mathrm{mg} / \mathrm{l}$ and NAA at 0.250 $\mathrm{mg} / \mathrm{l}$; gave rise to the highest number of shoots (4.00). This result was in agreement with that of Chuenboonngarm et al. (2001); Sayd et al. (2010) who obtained high proliferation of shoots of $G$. jasminoides through using BA. Also, Sutter (1996) reported that cytokinins are plant growth class used for encouraging division of cells, as well as for the formation and growth of axillary and adventitious shoots. Concerning the mean shoot length formed per propagule, there was an inverse relationship between BA levels and the given trait, i.e. as BA level increased, the mean value of given trait decreased, whereas MS-free-BA (0.00) reported the highest mean value (1.70) compare to the highest level of BA, i.e. $4.00 \mathrm{mg} / \mathrm{l}$, which recorded the lowest mean value (0.89). In case of NAA main effect, augmenting the culture medium with NAA at $0.250 \mathrm{mg} / \mathrm{l}$, brought about the highest mean value (1.49). While, the combinations between BA at $0.0 \mathrm{mg} / \mathrm{l}$ and NAA at 0.5 $\mathrm{mg} / \mathrm{l}$; recorded the highest mean value (1.92). Kozak (2011) observed a similar response due to the addition of BA; which resulted in a significant inhibition of shoot length. A supraoptimal level of BA suppressed the elongation of main shoot growth (Miler et al., 2005). Concerns the number of leaflets and the number of nodes formed per propagule, the presence of BA in the culture medium at $2.0 \mathrm{mg} / 1$; led to the highest mean values of the above-mentioned characters (9.44 and 4.74, respectively). On the other end, the main effect of NAA and the interaction between both growth promoters; enforced significant effect. In case of the main effect of NAA, the presence of NAA in culture medium at $0.250 \mathrm{mg} / \mathrm{l}$; achieved the highest mean values (8.69 and 4.42, respectively). The interaction between both BA and NAA at 4.0 and $0.250 \mathrm{mg} / \mathrm{l}$; achieved the highest mean values of the aforementioned characters (10.56 and 5.33, respectively). These results are in line with many researchers who investigated the various media and growth regulator combinations that have been exploit for tissue culture inform that shoot proliferation both as terminal buds in addition to axillary buds require the presence of cytokinins and auxins (Skrivin, 1984). Furthermore, several researchers have found that cytokinins, mainly BA, could stimulate axillary bud improvement, but at high concentration and shoot elongation is suppressed (Da Silva et al., 2003). With reference to the number of roots formed per propagule, the absence of BA and presence of NAA at $0.500 \mathrm{mg} / \mathrm{l}$; gave rise to the maximal mean number of roots formed per propagule (2.0). Regarding the callus size per propagule, the main effect of BA declared that the absence of BA from the culture medium resulted in the highest mean value (1.48). In case of NAA as main effect, augmenting MS-basal medium with at either 0.250 or $0.500 \mathrm{mg} / \mathrm{l}$; resulted in moderate callus size (1.19 and 1.22, respectively). Meanwhile, the combinations between both growth regulators BA at 0.0 and NAA at either 0.250 or $0.500 \mathrm{mg} / \mathrm{l}$; brought about an intensive callus size (2.11 and 2.00, respectively). Mizukami (1983) found that various auxins such as NAA and IAA could be used for induction and subculture of the callus in the presence or absence of cytokinins. Dumanois et al., (1984) reported that white loose callogenesis was derived from leaf explants in the presence of 2,4-D in the culture medium at $0.2 \mathrm{mg} / \mathrm{l}$ and $2 \mathrm{iP}$ at $0.2 \mathrm{mg} / \mathrm{l}$ or BAP $1 \mathrm{mg} / \mathrm{l}$, while brown-white callus tissues with newly formed roots were obtained in the presence of NAA in the culture medium at $1.0 \mathrm{mg} / \mathrm{l}$ and $\mathrm{KIN}$ at $0.5 \mathrm{mg} / \mathrm{l}$. Gardenia callus tissues grow well on chemically defined media (Ueda et al., 1981). 
Table 2. Effect of different levels of BA and NAA $(\mathrm{mg} / \mathrm{l})$ and their combinations on the multiplication stage of Gardenia jasminoides cultured in vitro for 5 weeks

\begin{tabular}{|c|c|c|c|c|c|c|c|c|c|}
\hline \multirow{2}{*}{ Characters } & \multirow{2}{*}{$\begin{array}{l}\text { NAA } \\
\text { levels } \\
(\mathrm{mg} / \mathrm{l})\end{array}$} & \multicolumn{4}{|c|}{ BA levels (mg/l) } & \multirow{2}{*}{$\begin{array}{l}\text { Mean } \\
\text { NAA }\end{array}$} & \multicolumn{2}{|c|}{ Significance } & \multirow{2}{*}{ BAXNAA } \\
\hline & & 0.000 & 1.000 & 2.000 & 4.000 & & $\mathbf{B A}$ & NAA & \\
\hline \multicolumn{10}{|c|}{ (a) Mean number of shoots formed/propagule: } \\
\hline & 0.000 & 1.57 & 1.87 & 2.50 & 2.50 & 2.11 & $* *$ & $*$ & $* *$ \\
\hline & 0.250 & 1.71 & 1.40 & 4.00 & 3.40 & 2.63 & & & \\
\hline & 0.500 & 1.50 & 3.00 & 3.00 & 3.00 & 2.63 & & & \\
\hline Mean (BA) & & 1.59 & 2.09 & 3.17 & 2.97 & & & & \\
\hline L.S.D. (0.05) & & & & & & & 0.43 & 0.37 & 0.74 \\
\hline \multicolumn{10}{|c|}{ (b) Mean shoot length $(\mathrm{cm}) /$ propagule: } \\
\hline & 0.000 & 1.44 & 1.52 & 1.73 & 0.63 & 1.33 & $* *$ & $*$ & $* *$ \\
\hline & 0.250 & 1.72 & 1.81 & 1.08 & 1.36 & 1.49 & & & \\
\hline & 0.500 & 1.92 & 0.56 & 1.06 & 0.67 & 1.05 & & & \\
\hline Mean (BA) & & 1.70 & 1.30 & 1.29 & 0.89 & & & & \\
\hline L.S.D. (0.05) & & & & & & & 0.33 & 0.29 & 0.58 \\
\hline \multicolumn{10}{|c|}{ (c) Mean number of leaflets formed/propagule: } \\
\hline & 0.000 & 8.78 & 9.56 & 7.89 & 8.11 & 8.58 & $* *$ & $*$ & $* *$ \\
\hline & 0.250 & 6.67 & 7.56 & 10.00 & 10.56 & 8.69 & & & \\
\hline & 0.500 & 5.44 & 8.00 & 10.44 & 6.56 & 7.61 & & & \\
\hline Mean (BA) & & 6.96 & 8.37 & 9.44 & 8.41 & & & & \\
\hline L.S.D. (0.05) & & & & & & & 0.95 & 0.83 & 1.65 \\
\hline \multicolumn{10}{|c|}{ (d) Mean number of nodes formed/propagule: } \\
\hline & 0.000 & 4.56 & 4.78 & 4.00 & 4.11 & 4.36 & $* *$ & $*$ & $* *$ \\
\hline & 0.250 & 3.44 & 3.89 & 5.00 & 5.33 & 4.42 & & & \\
\hline & 0.500 & 2.89 & 4.00 & 5.22 & 3.33 & 3.86 & & & \\
\hline Mean (BA) & & 3.63 & 4.22 & 4.74 & 4.26 & & & & \\
\hline L.S.D. $(0.05)$ & & & & & & & 0.48 & 0.42 & 0.83 \\
\hline \multicolumn{10}{|c|}{ (e) Mean number of roots formed/propagule: } \\
\hline & 0.000 & 0.00 & 0.00 & 0.00 & 0.00 & 0.00 & $* *$ & $* *$ & $* *$ \\
\hline & 0.250 & 0.00 & 0.00 & 0.00 & 0.00 & 0.00 & & & \\
\hline & 0.500 & 2.00 & 0.00 & 0.00 & 0.00 & 0.50 & & & \\
\hline Mean (BA) & & 0.67 & 0.00 & 0.00 & 0.00 & & & & \\
\hline L.S.D. (0.05) & & & & & & & $3.29 \mathrm{e}^{-9}$ & $2.85 \mathrm{e}^{-9}$ & 1.80 \\
\hline \multicolumn{10}{|c|}{ (e) Callus size formed/propagule: } \\
\hline & 0.000 & 0.33 & 0.67 & 1.11 & 0.00 & 0.53 & $*$ & $*$ & $* *$ \\
\hline & 0.250 & 2.11 & 1.89 & 0.00 & 0.78 & 1.19 & & & \\
\hline & 0.500 & 2.00 & 0.00 & 1.56 & 1.33 & 1.22 & & & \\
\hline Mean (BA) & & 1.48 & 0.85 & 0.89 & 0.70 & & & & \\
\hline L.S.D. (0.05) & & & & & & & 0.61 & 0.52 & 1.05 \\
\hline
\end{tabular}

L.S.D. $(0.05)=$ Least significant difference test at 0.05 level of probability.

*, **: Significant or highly significant.,ns: not significant 


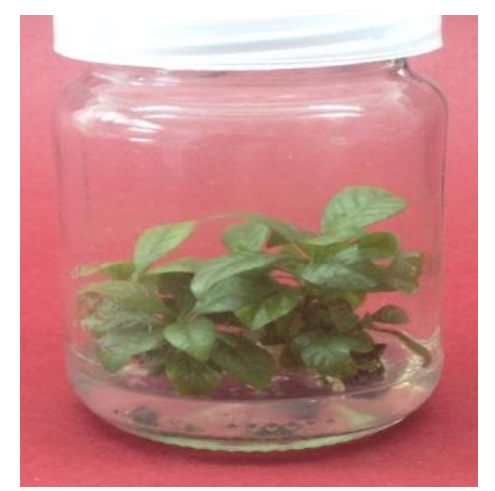

Fig. 2. Multiplication stage of Gardenia jasminoides, upon culturing newly formed nodal segments during of initiation stage then on MS medium augmented with BA and NAA at $2.0 \mathrm{mg} / \mathrm{l}$ and $0.250 \mathrm{mg} / \mathrm{l}$, respectively after 5 weeks of culture

\section{Rooting stage:}

Results of Table (3) and Figure (3) manifested that various levels of both applied growth regulators and their interactions had significant $(p \leq 0.05)$ effects on the rooting stage traits of $G$. jasminoides. Concerning the main effect of IBA tested levels on the mean number of shoots, the presence of IBA at $0.250 \mathrm{mg} / \mathrm{l}$; led to the highest mean value of the above-mentioned trait (1.40). On the other extreme, results manifested that NAA-freemedium; gave rise to the highest number of shoots (1.43). The interaction between IBA at $0.250 \mathrm{mg} / \mathrm{l}$ and NAA at $0.0 \mathrm{mg} / \mathrm{l}$, recorded the highest mean values of the defined character (2.00). With reference to the effect of both growth regulators and their interactions on the mean shoot length per propagule, it is obvious that, fortifying MS-medium with IBA and NAA at 0.500 $\mathrm{mg} / \mathrm{l}$; resulted in the highest mean value (2.95). As for the mean number of leaflets and nodes formed per propagule, the main effect of IBA and NAA, divulged that the presence of both growth regulators into MS medium had no significant effect on the given trait. Likewise, the interaction between IBA and NAA at 0.500 and $0.250 \mathrm{mg} / \mathrm{l}$, respectively, produced the highest mean value of the given traits (8.60 and 4.30, respectively). These results could be explained on the basis that auxin induce a number of responses which include initiation of root initials cell division, cell enlargement, protein and nucleic acids synthesis and changes in plant cell wall plasticity and increasing the apical dominance as there are essential and rapid processes participate in growth and development (elongation) (Wilkins, 1989). Respecting mean number of roots and callus size formed per propagule. The main effects of both growth regulators declared that there was a proportional relationship between the studied trait and their levels; whereas, fortifying the culture medium with the highest level of IBA $(1.0 \mathrm{mg} / \mathrm{l})$ and NAA $(0.5 \mathrm{mg} / \mathrm{l})$; gave rise to the maximum mean values of the studied traits as 1.77 and 2.95, respectively. However, the interaction between IBA and NAA exerted significant $(p \leq 0.05)$ effects on the given traits. These results proved that IBA and NAA as auxins have a role in rooting process since they enhance adventitious rhizogenesis. Root initial cells division depends on both endogenous and exogenous auxins concentration. The physiological effects of auxins are represented in increasing of cell division or converting the matured differentiated cells to shoots bases into meristematic cells, so adventitious root meristems will be formed and its cells will divide to produce adventitious roots (Nair et al., 2012). Growth regulators at optimal levels push the roots to grow in the presence of exogenous auxins, since increasing of auxins concentration promotes rooting on shoots (George et al., 2008). Respecting the callus size per propagule, results of both growth regulators and their interactions on callogenesis, exerted significant $(p \leq 0.05)$ effect and a proportional relationship between IBA and NAA and the given trait. The presence of IBA and NAA in culture medium at 1.0 and $0.5 \mathrm{mg} / \mathrm{l}$, respectively; resulted in producing high callus size. These results were in agreement with Kende (1989) who reported that providing IBA or NAA in culture medium promoted callus induction, and also rogues the promotive effect of some auxins viz., IBA, NAA and 2,4-D on callus induction and growth, and attributed the events to auxin as it promotes the biosynthesis of ethylene by increasing the activity of 1-aminocylopropane-1-carboxylic acid (ACC) syntheses. 
Table 3. Effect of different levels of IBA and NAA (mg/l) and their combinations on rhizogenesis stage of Gardenia jasminoides cultured in vitro for 5 weeks

\begin{tabular}{|c|c|c|c|c|c|c|c|c|c|}
\hline \multirow[b]{2}{*}{ Characters } & \multirow{2}{*}{$\begin{array}{l}\text { NAA } \\
\text { levels } \\
\text { (mg/l) }\end{array}$} & \multicolumn{4}{|c|}{ IBA levels (mg/l) } & \multirow{2}{*}{$\begin{array}{l}\text { Mean } \\
\text { NAA }\end{array}$} & \multicolumn{2}{|c|}{ Significance } & \multirow{2}{*}{ IBAXNAA } \\
\hline & & 0.000 & 0.250 & 0.500 & 1.000 & & IBA & NAA & \\
\hline \multicolumn{10}{|c|}{ (a) Mean number of shoots formed/propagule: } \\
\hline & 0.000 & 1.20 & 2.00 & 1.30 & 1.20 & 1.43 & $*$ & ** & ** \\
\hline & 0.250 & 1.00 & 1.20 & 1.00 & 1.20 & 1.10 & & & \\
\hline & 0.500 & 1.20 & 1.00 & 1.20 & 1.00 & 1.10 & & & \\
\hline Mean (IBA) & & 1.13 & 1.40 & 1.17 & 1.13 & & & & \\
\hline L.S.D. (0.05) & & & & & & & 0.22 & 0.19 & 0.38 \\
\hline \multicolumn{10}{|c|}{ (b) Mean shoot length $(\mathrm{cm}) /$ propagule: } \\
\hline & 0.000 & 0.96 & 0.96 & 1.00 & 1.49 & 1.10 & $* *$ & $* *$ & $*$ \\
\hline & 0.250 & 1.61 & 1.55 & 2.53 & 1.75 & 1.86 & & & \\
\hline & 0.500 & 2.26 & 2.40 & 2.95 & 2.21 & 2.46 & & & \\
\hline Mean (IBA) & & 1.61 & 1.64 & 2.16 & 1.82 & & & & \\
\hline L.S.D. (0.05) & & & & & & & 0.33 & 0.28 & 0.57 \\
\hline \multicolumn{10}{|c|}{ (c) Mean number of leaflets formed/propagule: } \\
\hline & 0.000 & 6.40 & 7.80 & 6.80 & 6.60 & 6.90 & ns & $\mathrm{ns}$ & $*$ \\
\hline & 0.250 & 6.50 & 6.40 & 8.60 & 6.60 & 7.03 & & & \\
\hline & 0.500 & 7.60 & 7.00 & 6.30 & 6.50 & 6.85 & & & \\
\hline Mean (IBA) & & 6.83 & 7.07 & 7.23 & 6.57 & & & & \\
\hline L.S.D. $(0.05)$ & & & & & & & 0.80 & 0.80 & 1.61 \\
\hline \multicolumn{10}{|c|}{ (d) Mean number of nodes formed/propagule: } \\
\hline & 0.000 & 3.20 & 3.90 & 3.40 & 3.30 & 3.45 & ns & ns & * \\
\hline & 0.250 & 3.30 & 3.30 & 4.30 & 3.30 & 3.55 & & & \\
\hline & 0.500 & 3.80 & 3.50 & 3.20 & 3.30 & 3.45 & & & \\
\hline Mean (IBA) & & 3.43 & 3.57 & 3.63 & 3.30 & & & & \\
\hline L.S.D. (0.05) & & & & & & & 0.47 & 0.41 & 0.81 \\
\hline \multicolumn{10}{|c|}{ (e) Mean number of roots formed/propagule: } \\
\hline & 0.000 & 0.00 & 0.00 & 1.00 & 2.50 & 0.88 & $*$ & $* *$ & $* *$ \\
\hline & 0.250 & 2.80 & 2.60 & 3.30 & 3.00 & 2.93 & & & \\
\hline & 0.500 & 3.00 & 3.30 & 2.70 & 2.80 & 2.95 & & & \\
\hline Mean (IBA) & & 1.93 & 1.97 & 2.33 & 2.77 & & 0.60 & 0.52 & 1.05 \\
\hline \multirow{2}{*}{\multicolumn{10}{|c|}{$\begin{array}{l}\text { L.S.D. (0.05) } \\
\text { (e) Callus size formed/propagule: }\end{array}$}} \\
\hline & & & & & & & & & \\
\hline & 0.000 & 0.00 & 2.00 & 2.00 & 3.00 & 1.75 & $* *$ & ** & ** \\
\hline & 0.250 & 3.00 & 3.00 & 3.00 & 2.50 & 2.88 & & & \\
\hline & 0.500 & 3.00 & 3.00 & 3.00 & 3.00 & 3.00 & & & \\
\hline Mean (IBA) & & 2.00 & 2.67 & 2.67 & 2.83 & & & & \\
\hline L.S.D. (0.05) & & & & & & & 0.10 & 0.09 & 0.18 \\
\hline
\end{tabular}

L.S.D. $(0.05)=$ Least significant difference test at 0.05 level of probability.

*, **: Significant or highly significant., ns: not significant
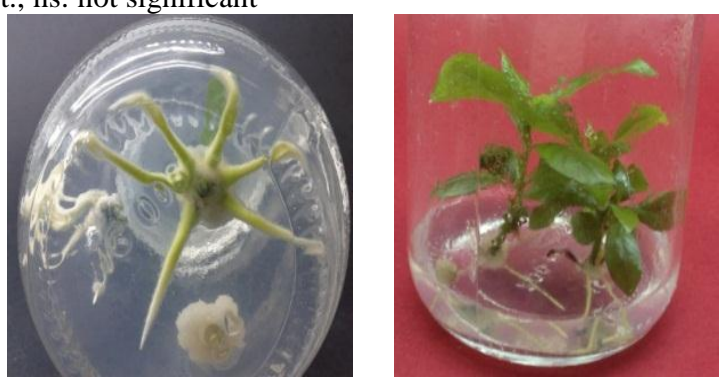

Fig. 3. Rhizogenesis of Gardenia jasminoides microshoots of multiplication stage, upon culturing them on MS medium fortified with IBA and NAA at 0.5 and $0.250 \mathrm{mg} / \mathrm{l}$, respectively after 5 weeks of culture 


\section{Somatic embryogenesis:}

The effect of various levels of 2,4-D on somatic embryogenesis of Gardenia jasminoides explants. The results presented in the given Table (4) and shown in Figure (4). Declared, obviously that different concentrations of 2,4-D exerted significant $(p \leq 0.05)$ effects on the studied traits of embryonic callus of $G$. jasminoides. Regarding the percentage of explants formed embryonic callus/propagule, the main effect of 2,4-D demonstrated, in general, that the presence of 2,4$\mathrm{D}$ into MS medium led to the highest percentage of explants formed embryonic callus/propagule (100\%). Respecting the callus size per propagule, results of 2,4$\mathrm{D}$ demonstrated that its presence in culture medium at $1.0 \mathrm{mg} / \mathrm{l}$, followed by $2.0 \mathrm{mg} / \mathrm{l}$; resulted in producing high embryogenic callus size (3.33 and 3.00, respectively) [which was white colour and friable]. For embryogenic callus induction and growth, an exogenous auxin supply is often recommended to initiate caulogenesis from the culture explant. Particularly, auxins affect growth and callus formation (Gamborge and Phillips, 1995). These results are in compromise with Lakshmia and Reddy (2012); Farzinebrahimi et al., (2014); Onsa et al., (2018) who reported that auxins, such as 2,4-D used to reactivate the cell cycle, initiate embryo formation and the best option of auxin, and widely used to encourage callus formation in many plants.

Table 4. Effect of various levels of both growth regulators 2,4-D on somatic embryogenesis of Gardenia jasminoides from node explants cultured in vitro for 5 weeks.

\begin{tabular}{|c|c|c|c|c|c|c|}
\hline \multirow{2}{*}{ Characters } & \multicolumn{5}{|c|}{ 2,4-D levels (mg/l) } & \multirow[t]{2}{*}{ Significance } \\
\hline & $\mathbf{0 . 0}$ & 0.5 & 1.0 & 2.0 & 4.0 & \\
\hline \multicolumn{6}{|c|}{ tage of embryogenic callus/propagule: } & $* *$ \\
\hline & 0.00 & 100.00 & 100.00 & 100.00 & 100.00 & \\
\hline . $(0.05)$ & & & & & & $1.41 \mathrm{e}^{-6}$ \\
\hline ogenic callus & gule: & & & & & $* *$ \\
\hline & 0.00 & 2.00 & 3.33 & 3.00 & 2.56 & \\
\hline . $(0.05)$ & & & & & & 0.53 \\
\hline
\end{tabular}

L.S.D. (0.05)

L.S.D. $(0.05)=$ Least significant difference test at 0.05 level of probability.

*, **: Significant or highly significant, ns: not significant

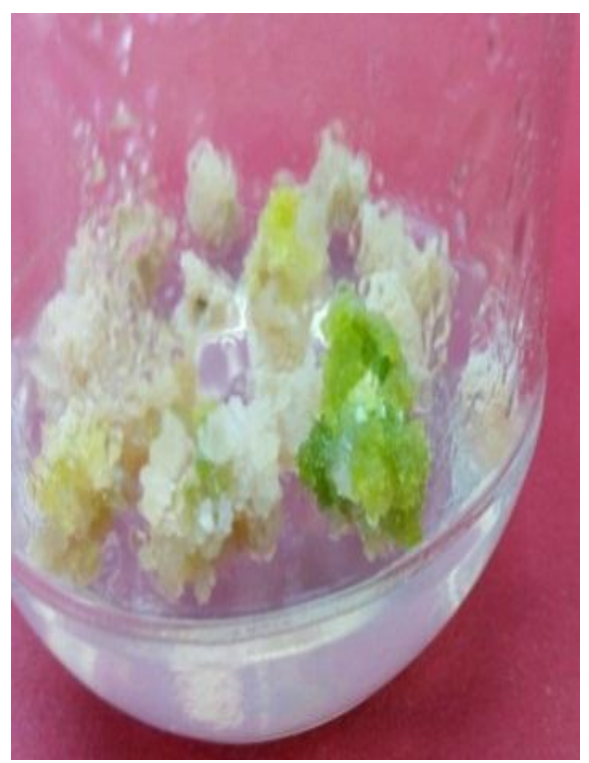

Fig. 4. Callus embryogenesis of Gardenia jasminoides due to culture nodal explants on MS medium fortified with 2,4-D at $1.0 \mathrm{mg} / \mathrm{l}$, after 5 weeks of culture 
Ex vitro and in vivo acclimatization of Gardenia jasminoides

Results presented in Table (5) exhibit that both applied mixtures of perlite and peatmoss $(\mathrm{v} / \mathrm{v})$ and their combinations, in addition to fixed volume (1 portion) of sand on acclimatization of neoformed plantlets of single node explants of $G$. jasminoides grown ex vitro for 28 days and as illustrated in Figure (5). Concerning the average of survival percentage, average number of neoformed shoots, average plants' height and number of newly formed leaves (true leaves) per plant, were affected significantly $(p \leq 0.05)$ effects on the given traits, due to adding peatmoss to the mixture at (1 volume); recorded the highest values $(50 \%, 4.22,16.14$ and 12.0 , respectively). On the other extreme, perlite had significant $(p \leq 0.05)$ effect on the given traits, too when added as 1 volume where recorded as $(50 \%, 3.19,15.90$ and 9.41, consecutively). Meanwhile, the interaction between peatmoss and perlite exerted significant $(p \leq 0.05)$ effect. However, the combination of peatmoss and perlite at $(1: 1)$; resulted in the highest mean value (100\%, 7.0, 22.22 and 17.11, respectively). In this respect, material as peatmoss is one of the most important constituents of mixture media due to its capacity in affecting plant growth either indirectly or directly. Indirectly, improves the physical conditions of mixture media by enhancing aggregation, aeration (8\%) and water retention $(77 \%)$, thereby creating a suitable environment for root growth (Sensi and Loffredo, 1999). On the other hand, perlite is known to have a moderate capacity to retain water (38\%) and provide' aeration (25\%) and its neural $\mathrm{pH}$ and the fact that it is sterile and weed-free. Hence, it is ideal for use in container growing substratum (Abido et al. 2016). Also, it is known that perlite decreases the bulk density of the soils and increases the porosity.

Table 5. The effect of different potting mixtures of perlite and peatmoss (v/v) and their combination on the acclimatization of neoformed plantlets of Gardenia jasminoides after four weeks ex vitro

\begin{tabular}{|c|c|c|c|c|c|c|c|c|c|}
\hline \multirow[b]{2}{*}{ Characters } & \multirow{2}{*}{$\begin{array}{c}\text { Peatmoss } \\
\text { levels }\end{array}$} & \multicolumn{4}{|c|}{ Perlite levels } & \multirow{2}{*}{$\begin{array}{c}\text { Mean } \\
\text { Peatmoss }\end{array}$} & \multicolumn{2}{|c|}{ Significance } & \multirow{2}{*}{$\begin{array}{c}\text { Peatmoss } \\
\text { X } \\
\text { Perlite } \\
\end{array}$} \\
\hline & & $\mathbf{0 . 0}$ & 1.0 & 2.0 & 3.0 & & Peatmoss & Perlite & \\
\hline \multicolumn{10}{|c|}{ (a) Average survival percentage (\%) / plant: } \\
\hline & 0.0 & 0.00 & 33.00 & 33.00 & 22.00 & 22.00 & $*$ & ns & $* *$ \\
\hline & 1.0 & 56.00 & 100.00 & 22.00 & 22.00 & 50.00 & & & \\
\hline & 2.0 & 89.00 & 22.00 & 33.00 & 44.00 & 47.00 & & & \\
\hline Mean Perlite & & 48.00 & 52.00 & 30.00 & 30.00 & & & & \\
\hline L.S.D. $(0.05)$ & & & & & & & 20.00 & 23.00 & 40.00 \\
\hline \multicolumn{10}{|c|}{ (b) Average number of neoformed shoots / plant: } \\
\hline & 0.0 & 0.00 & 1.33 & 1.33 & 1.33 & 1.00 & $* *$ & $* *$ & $* *$ \\
\hline & 1.0 & 5.22 & 7.00 & 1.33 & 3.33 & 4.22 & & & \\
\hline & 2.0 & 1.56 & 1.22 & 1.44 & 4.89 & 2.28 & & & \\
\hline Mean Perlite & & 2.26 & 3.19 & 1.37 & 3.19 & & & & \\
\hline L.S.D. $(0.05)$ & & & & & & & 0.29 & 0.33 & 0.58 \\
\hline \multicolumn{10}{|c|}{ (c) Average plant height $(\mathrm{cm}) /$ plant: } \\
\hline & 0.0 & 0.00 & 13.13 & 14.11 & 11.92 & 9.79 & $* *$ & $* *$ & $* *$ \\
\hline & 1.0 & 18.54 & 22.22 & 10.53 & 13.26 & 16.14 & & & \\
\hline & 2.0 & 18.01 & 12.34 & 14.44 & 17.74 & 15.64 & & & \\
\hline Mean Perlite & & 12.19 & 15.90 & 13.03 & 14.31 & & & & \\
\hline L.S.D. $(0.05)$ & & & & & & & 0.85 & 0.99 & 1.71 \\
\hline \multicolumn{10}{|c|}{ (d) Average number of neoformed leaves/plant: } \\
\hline & 0.0 & 0.00 & 5.56 & 7.78 & 5.33 & 4.67 & $* *$ & $* *$ & $* *$ \\
\hline & 1.0 & 14.89 & 17.11 & 5.78 & 10.22 & 12.00 & & & \\
\hline & 2.0 & 12.67 & 5.56 & 8.22 & 15.33 & 10.44 & & & \\
\hline Mean Perlite & & 9.19 & 9.41 & 7.26 & 10.30 & & & & \\
\hline L.S.D. $(0.05)$ & & & & & & & 0.93 & 1.08 & 1.86 \\
\hline
\end{tabular}

L.S.D. $(0.05)=$ Least significant difference test at 0.05 level of probability.

*, **: Significant or highly significant.,ns: not significant 

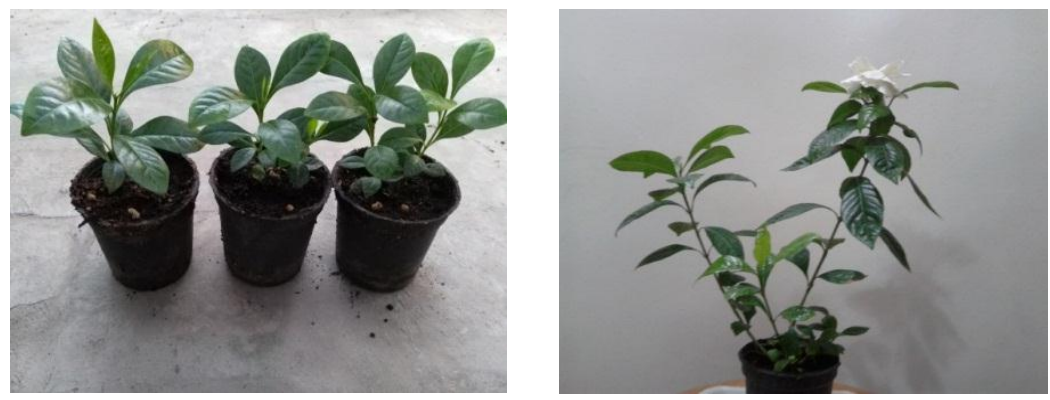

Fig. 5. Acclimization of neoformed Gardenia jasminoides plantlets ex vitro (left), then mature plant (right) grown in combination of perlite and peatmoss at $(1: 1, v / v)$

\section{REFERENCES}

Abido, A.I. 2016. Acclimatization of plant tissue culture derived plants (Theory and Application). Dar El Hoda Pup. Alexandria, Egypt, 267.

Al-Juboory, K.H., R.M. Skirvin and D.J. Williams. 1998. Callus induction and adventitious shoot regeneration of gardenia Gardenia jasminoides Ellis/ leaf explants. Sci. Hort., 72: 171-178.

Chavan, J.J., N.B. Gaikwad, S.D. Umdale, P.R. Kshirsagar, K.V. Bhat and S.R. Yadav. 2014. Efficiency of direct and indirect shoot organogenesis, molecular profiling, secondary metabolite production and antioxidant activity of micropropagated Ceropegia santapaui. Pl. Grow. Reg., 72: $1-15$.

Chuenboonngarm, N., S. Charoonsote and S. Bhamarapravati. 2001. Effect of BA and 2iP on shoot proliferation and somaclonal variation of Gardenia jasminoides Ellis in vitro culture. Sci. Asia. 27: 137-141.

Da Silva, A.L., M. Rogalski and P.M. Guerra. 2003. Effect of different cytokinins on in vitro multiplication of prunus 'Capdeboscq' rootstocks. Crop Breed. \& Appl. Biotech., 3 (2):149-156.

Duhoky, M.S. and K.A. Rasheed. 2009. Micropropagation of Gardenia Gardenia jasminoides by using single nodes. Mesopotamia J. Agric., 37 (3), p13.

Duhoky, M.S. and K.A. Rasheed. 2010. Effect of different concentrations of kinetin and NAA on micropropagation of Gardenia jasminoides. J. Zankoy Sulai., 13: 103-120.

Dumanois, C., B. Godin and C. Bigot. 1984. Multiplication vegetative in vitro de: Gardenia jasminoides Ellis. J. Pl. Physiol., 116: 389-407.

Economou, A.S. and M.J. Spanoudaki. 1985. In vitro propagation of gardenia. Hort. Sci., 20(2): 213.

Economou, A.S. and M.J. Spanoudaki. 1986. The influence of cytokinins and Gibberellic acid on gardenia tissue cultures. Sci. Hortic., 29: 155-161.

Farzinebrahimi, R., R.M. Taha, K. Rashid and J.S. Yaacob. 2014. The Effect of Various Media and Hormones via Suspension Culture on Secondary Metabolic Activities of (Cape Jasmine). Sci. World J. doi: 10.1155/2014/407284.
Gamborge, O.L. and G.C. Phillips. 1995. Media preparation and handling. In: Plant Cell, Tissue and Organ Culture. Funda. Methods. Springer, Germany, 21pp.

George, E.F., M.A. Hall and G.J. DeKlerk. 2008. Plant Propagation by Tissue Culture, Third Edition, Springer, Dordrecht, Netherlands.

Gomez, K. and A.A. Gomez. 1984. Statistical procedures for Agricultural Research ( $2^{\text {nd }}$ ed.). An International Rice Research Institute Bok. A Wiley Interscience Publisher, New York.

Graf, A.B. 1981. Tropica, $2^{\text {nd }}$. Ed., p: 1009, Roehrs Company, NJ.

Gruselle, R., N. Badia and P. Boxus. 1987. Walnut micropropagation. First results. Acta. Hort. 212:511-515.

Jarrar, A. and R. Bayerly. 2011. Effect of Some Growth Hormones on Multiplication and Rooting in vitro MicroPropagated of Gardenia Plant (Gardenia jasminoides.L.) cv. Ellis. Agri. Sci. Res., Dama., 27 (1): 129-142.

Kende, H. 1989. Enzymes of ethylene biosynthesis. J. Pl. Physiol., 91 (1): 1-4.

Kozak, D. 2011. The influence of light quality and BA on in vitro growth and development of Gardenia jasminoides Ellis. Acta Sci. Pol., Hortorum cultus. 10(4) 2011, 65-73.

Kyoichi, N., S. Yamaguchi and Y.Ohnuma.1987. Studies on the shoot tip culture of sweet cherry, European pear, and grapevine. Bulletin of Yamagata Prefect. Hort. Sci. Exp. Stat, 6:19-37.

Lakshmia, B.J. and K.J. Reddy. 2012. In vitro studies in dikamali gum (Gardenia resinifera roth.) - A medicinally important plant. Indian J. Sci. Res. 3(1): 81-86.

Miler N., M. Zalewska and J. Lema-Rumiska. 2005. The influence of light colour on the quality of chrysanthemum microcuttings rooted in vitro. Zesz. Probl. Post. Nauk Roln. 504, 153-158.

Mizukami, H. 1983. Gardenia jasminoides Ellis: In Vitro Propagation and the formation of Iridoid glucosides. Biotech. Agri. \& Forest., 7: 213-226.

Murashige, T. and F.A. Skoog. 1962. Revised medium for rapid growth and bioassays with tobacco tissue culture. Physiol. Pl., 15: 473-497. 
Nair, R.R., M. Kavitha, S. Thilaga and D. Ganesh. 2012. Conservation and in vitro multiplication of highly endangered Indian traditional medicinal plant (Morinda reticulata Gamble) through nodal explants. Pl. Knowl. J., 1(2): 46-51.

Onsa, R.A.H., I.A. Abdellatif, M.G. Osman and T.L. Abdullah. 2018. Effect of Growth Regulators In in vitro Micropropagation of Ixora coccinea. Intl. J Sci. \& Res. Pub., 8 (11): 144-149.

Pasqual, M. and A. Audo. 1989. Micropropagation of trifoliate through axillary buds in in vitro culture. Pesquisa Agrope-Cuaria Barsileira. 24: 217-220.

Penuela, R., C. Garavito, R. Sanchez-Tames and R. Rodrguez. 1987. Multiple shoot-bud stimulation and rhizogenic induction on axillary shoots of walnut embryonic axes (Abstract) In: Intl. symp. Veget. Propag. woody Sp., Pisa, Italy, pp 98.

Razdan, M.K. 2003. Introduction to Plant Tissue Culture. 2nd Ed., Science Publishers, Inc.

Salim, S.R. and S.Y. Hamza. 2017. An Efficient Protocol for Micro Propagation of Gardenia jasminoides Ellis. BIO. SCI. BIOTEC. RES. ASIA. 14(2): 757-766.

Sayd, S.S., H.A. Taie and S.L. Taha. 2010. Micropropagation an antioxidant activity, total phenolics and flavonoids content of Gardenia jasminoides Ellis as affected by growth regulators. Intl. J. Acad. Res., 2(3): 184-191.

Sensi, N and E. Loffredo. 1999. The chemistry of soil organic matter. In: Spark, D.L.(Ed.), Soil Physical Chemistry. CRC Press, Boca Raton, FL, pp. 239-370.
Skirvin, R.M. 1984. The tissue culture of stone fruit In: Handbook of Plant Cell Culture volume 3.Crop Species. Ammirato .P.V, D.A. Evans, W.R. Sharp and Y. Yamada (eds). Macmillan. New York, pp.402- 452.

Skoog, F. and C.O. Miller. 1957. Chemical regulation of growth and organ formation in plant tissues cultured in vitro. Symp. Soc. Biol. Exp. Biol., 11:118-148.

Snir, 1982. In vitro propagation of sweet cherry cultures. Hort. Sci., 17:192-193.

Steel, R.G.D., J.H. Torrie and D.A. Dickie. 1997. Principles and procedures of statistics-abiometric approach. Third edition. McGraw-Hill Publishing Company. Toronto.

Stern, K.R., S. Jansky and J.E. Bidlack. 2004. Introductory Plant Biology. The Mc Graw-Hill companies. Inc.Bon.

Sutter, E.G. 1996. General laboratory requirements, media and sterilization methods. In: Plant tissue culture concepts and laboratory exercises. (Edited by Trigiano RN and Gray DJ), pp 11-25, CRC Press, Inc Boca Raton.

Ueda, S., K. Kobayashi, T. Muramatsu and H. Inouye. 1981. Studies on monoterpene glucosides and related natural products. Part XL. Iridoid glucosides of cultured cells of Gardenia jasminoides and $f$. grandifolia. Pl. Med., 41:186-191.

Wilkins, H.F. 1986. Gardenia jasminoides. In: Handbook of flowering. Volume V (Edited by Halevy AH), pp: 127131, CRC Press, Inc USA.

Wilkins, M.B. 1989. Advanced plant physiology. The Bath Press, Avon, 13-15. 


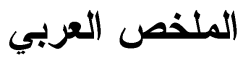

\section{الإكثار المعملى الاقيق واسحثاث تكوين الاجنة الجسمية لنباتات الجاردينيا}

$$
\text { محمد قدرى جابر، أحمد عبد المنعم بركات }
$$

التضاعف (الإكثار). وفيما يتعلق بالتجذير، كونت المجاميع الخضرية الحديثة المنتجة من التضاعف الخضرى جذورا

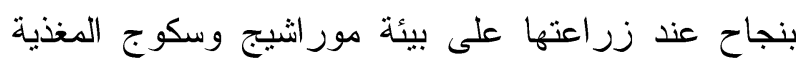

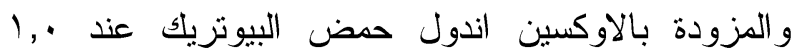

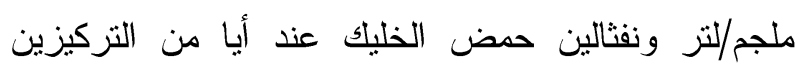

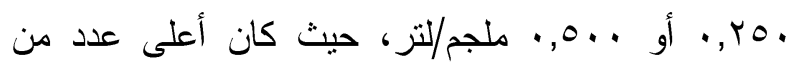
الجذور قد سجل، بالإضافة إلى استحثاث تكوين الكالس. وفيما يتعلق بإستحثاث الكالس الجنينى، فإن اضلى الفافة

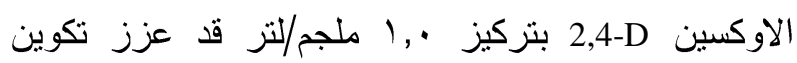
الكالس الجنينى. ولقد تمت أقلمة النبيتات الحديثة النكوين خارج أو عية الزراعة بنجاح فى خلطة زر اعة من البيرليت

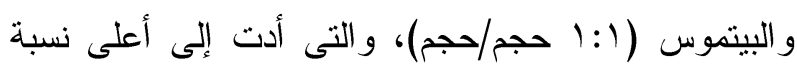

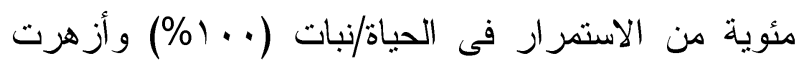
النباتات بنجاح وأوضحت شكلا مظهريا مطابقا للنبات الأم.
الجاردينيا من النباتات مستديمة الخضرة لون أزهارها

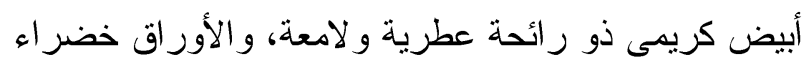
داكنة، تتنمى الى العائلة Rubiaceae. تهتم هذه الدراسة بتقديم تقنية جديدة للإكثار المعلى الدقيق وإستحثاث كالس

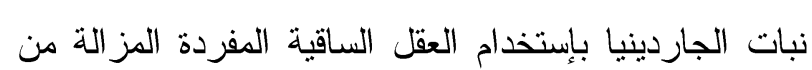

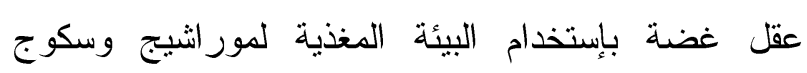

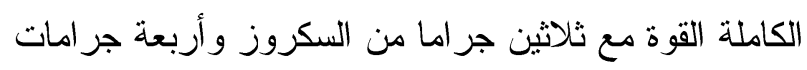

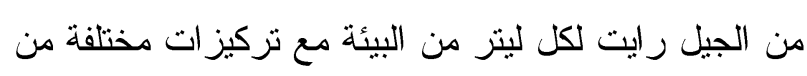

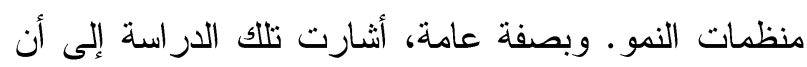

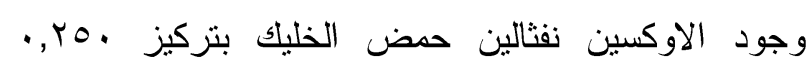

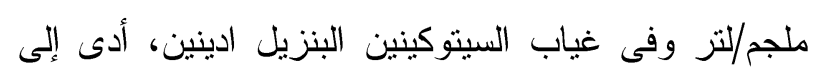

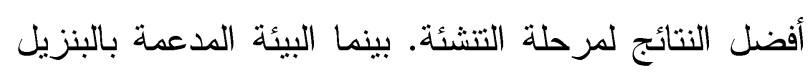

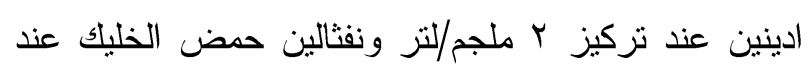

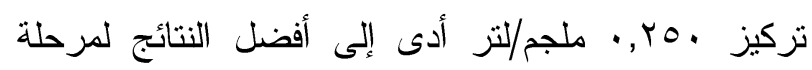

